\title{
Chapter 9 In Antigone's Shadow: Valentina
}

"But my story is bloody. All, all history is made with blood, all history is blood, and tears are not seen. Crying is like water; it washes and leaves no trace. Time, what does it matter? Am I not here without time now, and almost without blood, but by virtue of a story, entangled in a story? Time may pass, and the blood does not run anymore, but if there was blood and ran, the story continues to stop time, entangle it, condemn it. Condemning it. That is why I do not die, I cannot die until I am given the reason for this blood, until history goes away, letting life live. Only living can you die."

María Zambrano, La tumba de Antígona

One has to be brave to live without living. Valiant indeed is she, Valentina, like Antigone, both from the same lineage. The myth of Antigone has captivated our imagination in multiple plays and operas. ${ }^{2}$ María Zambrano wrote La tumba de Antígona as a play during her residence in La Pièce, France, and published it in 1967 in Mexico. As Anna Formentí points out:

While in the work of Sophocles, Antigone is moved by her anger for being misunderstood and abandoned by these gods to whom she had devoted herself and she ends her life once she enters the grave; in Zambrano's adaptation of the myth Antigone will be reborn in her grave with a single purpose: to give herself the form and content never enjoyed in life. Actually, Zambrano's version is the only one that allows a true existence of Antigone as a person, and that is why Zambrano differs from Sophocles when he says that she committed suicide in 
her grave: "But could Antigone kill herself, she who had never disposed of his life?" [Zambrano's words] That way Zambrano turns the tomb of Antigone into the cradle of her nascent being. Zambrano tries to illuminate what in the tragedy of Sophocles is dark; the interior of her main character, the reason and unreason that Antigone keeps in her entrails not able to come to light, her fears and her grudges, everything she does not know about herself and will discover as she approaches her end. Zambrano intends to rescue Antigone's life not lived, since, as the philosopher points out in the prologue, Antigone's essence in life was that of sacrifice: "This essence was substance, the raw material of sacrifice that sacrifice can only consume."

It is precisely that non-living or non-being that Valentina incarnates, just like Antigone. Valentina buried her needs and feelings early in her life in support of those around her. Yet, she represents the tenacious resilience of women, mostly outside the view of history, whose sacrifices were significant for the survival of Spain after the civil war and its ultimate emergence as a modern European democracy.

Born in 1943, Valentina, the oldest of five siblings, quickly learned to accept she had to put herself last when it came to family matters. The 1940s were the "hunger years," years of autarchy and misery for a devastated population after the cruel civil war. Hunger and violence were quotidian comings and goings in her life.

"Si en la obra de Sófocles, Antígona, movida por la furia de la incomprensión y el abandono que siente por parte de estos dioses a quienes se ha consagrado enteramente, pone fin a su vida una vez entra en la tumba, en la obra de Zambrano ésta renacerá en su tumba con un único propósito: darse el ser, la forma y el contenido que en vida nunca se dio. En realidad, la opción de Zambrano es la única que permite una verdadera existencia de Antígona, de la persona Antígona, y por esto Zambrano difiere de Sófocles cuando dice que ella se suicidó en su tumba: 'Mas ¿podía Antígona darse la muerte, ella que no había dispuesto nunca de su vida?' De esa forma convierte Zambrano la tumba de Antígona en cuna de su ser naciente. Zambrano intenta alumbrar lo que en la tragedia de Sófocles queda a oscuras; el interior de su principal personaje, las razones y sinrazones que Antígona guarda en sus entrañas y que no han podido salir a la luz, sus miedos y sus rencores, todo aquello que desconoce de ella misma y que va descubriendo a medida que se acerca a su fin. Esa vida no vivida de Antígona es lo que Zambrano pretende rescatar, puesto que, como dice en el prólogo, su esencia en vida fue la del sacrificio: 'Esta esencia era sustancia, materia prima de sacrificio que el sacrificio solo puede consumir." Anna Formentí, "La tumba de Antígona" (México: Siglo XXI, 1967). htt p://www.ub.edu/smzambrano/resenyas/LA_TUMBA_DE_ANTICONA.pdf [my translation]. 


\section{ACT I: Early Life}

La historia, niña Antígona, te esperaba a ti, a ti.

Por eso estás aquí, tan sola. Por la historia ${ }^{4}$

I was born in Córdoba on July 18, 1943. My siblings were born there too. Three. One more was born in Granada. And my parents were in Córdoba for about 4 years or so [...] After about 4 years or so, it's when I came back from there, from Córdoba. We moved into my grandparents' house, a very large house they owned.

They were a well-to-do family. And in the war, they had to move to the other side, as they say. To communism, because his brothers [referring to her father's siblings] fled while two women stayed behind here. And because of terror, of fear, because they [referring to the fascists] hunted them, took them out, and mistreated or raped them, they fled too. And when they came back, [after the war] they found the house was plundered...because anyway...they had paintings...good paintings and some relics, and they had land. They had everything and then from having had everything they found themselves with no more than night and day.

Well, my mother and my father also left. They lived in the Guadix's area and decided to get married because everyone was telling them to get married. But then when they came back to our village, they were told those marriage papers were invalid, so they had to remarry in Atarfe, in the church, and in court and everything. So, they are married for good. They got married by the church, yes. And then as life was so hard in those years, oh so bad...well, they migrated to Córdoba. Because let's say like an emigration, you know? In Córdoba there were better off people who rented land to work. And then, at the end of the year's harvest the foreman received a percentage. So, my parents left for Córdoba. While my mother sewed in the owner's house, my father got the job of foreman.

What happened? Well, after four years, seeing that they did not pay him or give him any explanations, my father went and asked the owner what was happening. He said he wanted to clarify before he continued or stop working the land. And then, you know what that man did? He called them one by one into his office with a gun in his hand... and told him [Valentina's father] to sign as if he had given him his money. [she paused] My father told me that story and did not want me to ever repeat it. But now I'm telling you. Because they [referring to her parents] were afraid. And then, they had to go in and sign one by one and after signing and not giving them anything, they had to come back to our town without a penny, without a house, with nothing. Luckily, my uncles had not sold the family house and we all moved in with my uncles and lived there for a number of years. After a few years, they sold the house and distributed the money...so then we left. My parents built a house, where we were raised. Until I was 18...because I remember RATION CARDS [she emphasized] since I was the oldest girl in my house and my mother was going to serve the family...because my father,

$4 \quad$ "History, my child Antigone, was waiting for you, you. That is why you are here. Because of history." Zambrano, La tumba de Antígona, loc. 737 of 1423, Kindle [my translation]. 
being from a well-to-do family, he didn't want us to be servants of anybody, or to work in the fields...nothing. Better to starve because once we had been a well-to-do family. However, my mother was doing housework for his family. She was, let's say, cleaning up their shit [pause]. To clean, to wash clothes, to help with the matanza, ${ }^{5}$ everything. And then she would come back with sticks of tobacco we would burn for cooking. With the tobacco sticks we cooked and all that. What happened then? That is when I was about to turn eight years old, and my parents had their last baby. That meant I couldn't go back to school or anything anymore. I had to stay home to help raise my sister. I was only eight years old...not quite, because my sister was born in February and I turned eight in July. Well, of course, my mother she couldn't do it...because his [referring to her father] family didn't give her, let's say only...old leftover bread and used oil after having fried the fish. LEFTOVERS. IN A WORD, LEFTOVERS! But you had to shut up. For my parent's sake I had to shut up. Because they came from rich people and we could not complain. Well, ALWAYS REPRESSED. You could not talk. However, we never did go to bed starving. Truth be told. But we had to eat whatever someone else did not want and left for us.

I fed my sister, this little baby girl. I gave her bottles of goat's milk because my mother did not have breast milk. And then, I used to buy a quarter of a liter of goat's milk and when I was older, I used to dunk bread in it, you know? And some other times, I made toasted flour gruel...I roasted the flour [Valentina recalled with pride] and sometimes I added a little extra water [laughing] for me to try a little spoonful of the gruel...only eight years old. My sister slept with me. Of course, there were no diapers available like nowadays, so I was soaked in pee every morning. I had to wash my clothes, close the door, in my underwear, and hang the clothes to dry. Then, I put them back on and with my sister I did almost the same thing with her, with the little baby girl, as in those times they were thick fabric wraps and all that... and I had to remove them when she peed and it smelled and the stink really bothered me.

We had a portal entrance... a zaguan (hallway). There were the houserooms and there were these portals about three meters wide. Then, in what is the middle, there were cobble-stones like a river basin and my father, I remember him throwing water over the cobblestones and I on my knees with a... [thinking] a ... a heavy rug mop...you had to tame that rug and I dried the stones until they shined. And my father was such a brute that he kept throwing the water...pouring it with a pail, he threw the water like that...buckets, imagine going out on the patio...while I kept kneeling down...drying that... The house was always clean. I was eight or nine years old, but I was a tiny girl. My father always closed the door so nobody would see him doing housework. Because they would think he was no longer a real man.

Later on, when I was ten, I started to embroider veils. My mother taught me how to sew; she taught me how to make patches; she taught me how to make underpants. I did all that without going to school after I turned eight years old. I still kept my school bag. [she giggled] So, I grew up without knowing how to read or write. 
We raised pigs, chickens. I did all that. I remember the smell of brown bread and potatoes, which we fed to the pigs... The bran, that was it...and I wanted to eat that. And I ate it every once in a while...I ate the bran. I liked it. And almost every year my father worked in the drive of the sugar production at a factory in la Vega. But they always fired him by Christmas and we sacrificed a pig...we had to kill a pig and a few chickens, ten, twelve chickens for Christmas. He used to return and simply go to bed.

Well, we had to sell the chickens. We had to sell the pig.... And in addition to all that, I had to cook, and I remember my mother used to give me two or three duros ${ }^{6}$ and she sent me to the market and said, "Daughter, try to bring enough for lunch and dinner." I brought the best I could, to make a noodle casserole, or beans, or chickpeas, or whatever. Because I've always been a little devil [mischievous smile] I went to the butcher shop and demanded, "Give me two or three pieces of that meat" and then I would say, "I have only this much [referring to money] and the butcher would say, "but this is all you pay me?" And I replied, "that's all I have. And you also have to give me that little piece over there because it's the one I like." And [laughing] because the butchers loved me, they gave it to me. Then, I was able to cook and my mother...that was in the winter season and the tobacco season, she went to harvest tobacco and in the summer season, it was the corn. My mother, because my father continued with the same ideas that we were well-to-do people and we couldn't [do manual] work. My mother could, but we could not. That went on until I turned eighteen. When I turned eighteen, there were four months of storms and my twelve-year-old brother was already working in a bakery. And they paid him with a bread loaf and a half and a duro and with that we maintained our household.

Sometimes my mother would get some old dresses from our relatives, and the poor woman made new garments out of such rags. She cut them up and made all new clothes. But in the first wash, they would come apart on the washing board. All of this until I turned eighteen years old. By that time, my brother was already fed up with his job at the bakery because he was only given twenty duros a month and one and half loaves of bread. But he would start at five in the afternoon and work till dawn. He wouldn't arrive at the house until seven in the morning. So, the poor thing was very fed up and he had already turned twenty years old. So, it happened that an uncle of mine from Córdoba had migrated to Barcelona. We found out he was in Barcelona, and my brother wrote to our cousins and then my uncle, and they said we shouldn't think twice about coming, and even if we all slept on the floor, we were welcome to move in with them. My brother left two months before me. And my father and I followed him in September. I remember we arrived on the festivity of the Virgin of La Merced...in '61. There we were, three families in three bedrooms, a kitchen, and a dining room flat. [Valentina paused] There we went. On the Day of our Lady of the Merced, a Saturday or Friday, and by the following Tuesday we were looking in La Vanguardia newspaper for jobs. We realized they preferred to hire Catalans for these jobs; we were not welcome. They did not want us...not at all...They did not speak Spanish to you because they wanted you to learn it [Catalan]. 
Nowadays they are more willing to speak Spanish than in the 60s. So, I arrived...I arrived on a Saturday, as I've already told you, and the following days we grabbed La Vanguardia on Monday, on Tuesday....

On a Monday I arrived at my first job and the manager saw me. He was Catalan and he told me...in his house they did not even like Andalusians...so I said, "Very well..." as in those days there was plenty of work in Barcelona and I would go elsewhere. But then, he said "I don't know why I like you," ...because, you see, there [referring to Barcelona in those times] they were very respectful towards you.... He said, "Come back tomorrow, Tuesday, and I will test your skills." And he tested me and hired me. The test consisted of making a bra within an hour and a half, and I finished it in three quarters of an hour. So, he hired me.... Then he said, "Come on Friday. We start the week on Friday, from Friday to Friday." I had left a small village and suddenly found myself as if in New York...because Barcelona was just like our New York at that time.

That was my first job, 23 Condal Street, a corsetry workshop which produced bras, swimsuits, underwear, what else was it? [Valentina paused to remember] girdles... I mean underwear of all kinds. And I specialized in bra cups, built with some padding. There was another girl who also made the bra cups, but she made them two sizes smaller and I made sure to stitch a little further out. So the boss told her to try to make them a size larger because hers were returned. You see a size 95 must be 95 and hers felt more like size 90. And I made them exactly 95 .

So, if it were supposed to be 95 it was indeed size 95 . The boss really liked my work and made me a specialist in making the bra cups and for making the salesmen's samples... Yes, samples were my job too. Even lace samples, and the boss paid me a bonus for those. Because I would work on the lace for twelve hours.

They paid me one cent for some, and two cents for others. The most laborious were worth two and a half. And I earned in those times per week over 3,000 pesetas, almost 4,000 pesetas in the sixties...that was about 12,000 or 13,000 pesetas. Well paid, of course it was...but I worked twelve long hours. 
Figure 32: Corsetry factory employees pose in their uniforms, Barcelona c. 1962

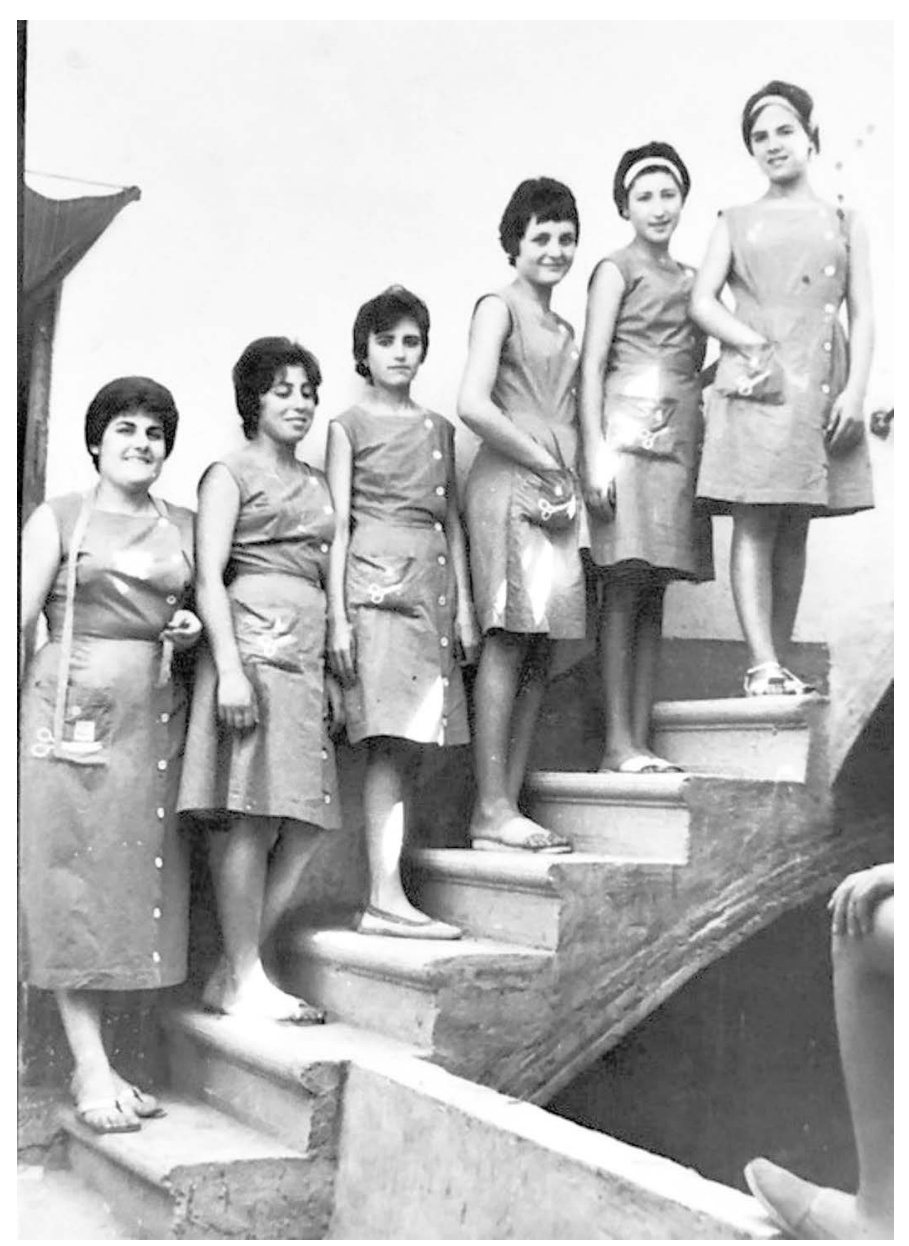

And then, I would return home to make lunch for my father and for me. That went on for three months...cooking for my father, for my brother, and for me. It was during those three months when suddenly my father decided that he did not like Barcelona and told us he wanted to return to Andalusia. We told him we were not going back there to so many debts and no work. So my father suggested we go out for a ride on the bus to the city center and when we saw him acting so kindly...something we had never seen from him as he was never affectionate, but of course, that kindness had a motive... He was a typical brute as men were in those days. 
Figure 33: At work in the corsetry factory

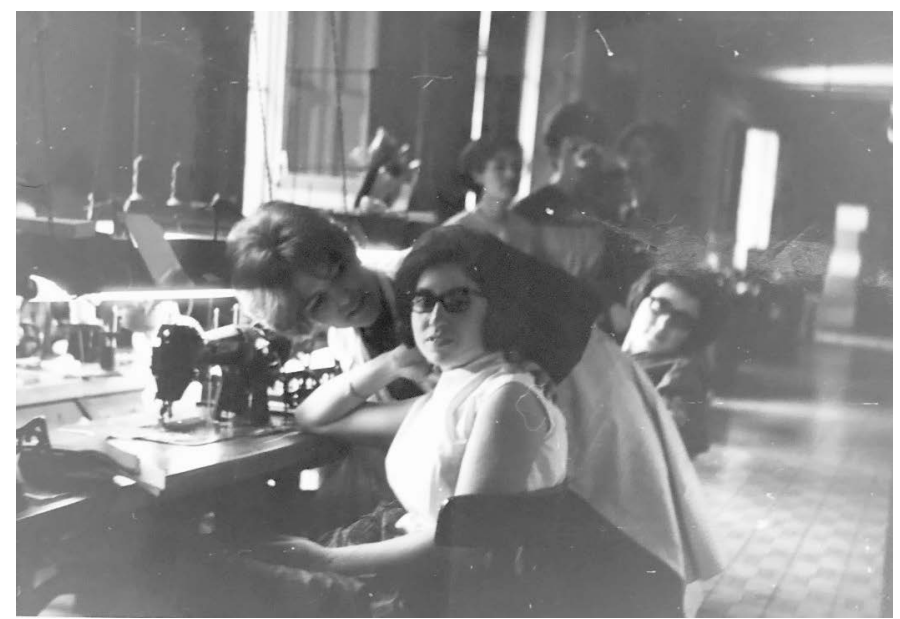

And then I said, "All right, Papa, where are we going?" And then he said, "To buy the tickets to return home." THEN, I pulled the emergency stop cord on the bus and it stopped and we three got off. My brother got off and I got off...well, he [Valentina's dad] had to get off. When we got off, we took a walk to a nearby park. He kicked my brother... [nervous laugh] and he gave me a big pinch and slapped me across my face...that...I will not forget in life. And I told him that if he wanted to take the train back to go ahead and my brother took my side. "Papa, do you realize what problems we left there in Granada, even suffering what we are going through here.... And my dad said, "I cannot stand the Catalans," [severe tone] and we replied, "We come to take away what is theirs; it is like the one who goes abroad." Well, we are not the same because we are all Spanish but...still, we came to take, as we say now, from those around here. We came to take their work...and that's how it happened. Neither his hitting us nor his raging anger would move us.... We stayed there, and so did he.

The worst was not over. He started to drink heavily, like my uncle. My father used to drink a little but then being so unhappy made him and my uncle drink and drink. You see, he used to give me half of his week's pay and my brother gave me the entire week's pay except for some pocket money. And I saved my entire week's wage. We had to save money for a deposit in order to move out of my relatives' flat. I HAD TO COLLECT 40,000 PTS THEN IN THE 60S... [Valentina emphasized] and then, buy furniture. It was not worth bringing furniture from the south because it cost you more than buying it there second hand.

So, my father every night asked me when no one saw us, "Give me money." And I would say "Money? I don't have it anymore; I am truly sorry." ...From an angel girl I turned into an evil girl. Already, my rebellion within overpowered me more than anything else, because it was always beatings, slapping me around, and punishing me nonstop...just the way it 
was in those times. THAT ABUSE IS WITH YOU FOREVER, NOTHING IN THE WORLD MAKES IT POSSIBLE TO FORGET....

Well, he kept asking me for money and I kept saying NO...he would go into a rage, checking my suitcase, he then would search me, search my uncle...everyone... and I would tell him that I had the money in a sacred place. And he screamed, "If you have opened a savings account, I assure you that I'll kill you. ... He would not...he was not going to kill me because he was my father. The money was in a missal that I...see...in my youth, I was so pious...as they forced me to be...and in a missal inside a sheath cover I had been hiding the money in between the pages. Every page would guard a twenty duros bill note, another sheet of the book, another twenty duros bill. Little by little until I saved...I don't know... about sixty or seventy thousand pesetas. I PUT IT IN THERE! That missal had its cover, with the engraved word "Missal," which kept my father at bay.

Valentina looked at me with great pride, triumphant, as she revealed the beatings she endured to save the little fortune. In her tone she cogently conveyed how every blow was worth it. How resisting the blows was more powerful now that she unveiled the secret, sacred bank. Every blow made her feel freer. She continued her story:

If I hadn't done so I would not have been able to save a cent. Because he started drinking and I needed my mother to join us in Barcelona because I could not throw away my life. I could not endure it any longer. I remember in the house where we lived there was a young man who had studied. He was a nephew of an aunt of mine. Someone with enough schooling to be able to attend college if he had wished to. We had a long bus and subway ride to work every day...and one day I told him I could not read and write. He said, "Tina, really, you cannot write?" And I said, "Well, I don't know how to write, Pepe; I don't know how to read or write."7 So, he gave me a book and said, "If I give you some homework, would you learn?" And I said I would do as he said.... "You could study on the subway," ...he said...and I would say, "Do you know how to teach me, Pepe?" And he said, "YES." So, I said then, "Make it so that I will study and bring the homework to you to review it and correct it every night." YES! AFTER TWELVE HOURS OF WORK, I went back to housework, making dinner, and the next day's meal... and I studied on the public transit. And SO, I LEARNED TO READ AND WRITE. I read my books. I don't read now as much as I read then. I do not read now because of my poor eyesight... I LEARNED TO READ AND WRITE. Those books about famous people. Leftists rather than rightists' books, you know? ... But I can't tell you the titles. They were small books and then he gave me an encyclopedia that was quite from the left rather than the right.... 
Valentina-Tina-learned to read and write, saved enough money to bring the rest of the family to Barcelona where they stayed and were able to move to their own flat. She reached her full potential, a strong independent woman.

\title{
ACT II: Love and Marriage
}

\author{
$Y$ ahora necesito saber el porqué \\ de tanta monstruosa historia. ${ }^{8}$
}

The virgins are here to prove a point.

The virgins are here to tell you to fuck off.

The virgins are certain there's a circle of hell.

dedicated to that fear you'll never find anyone else. ${ }^{9}$

Figure 34: Young women posing in the courtyard

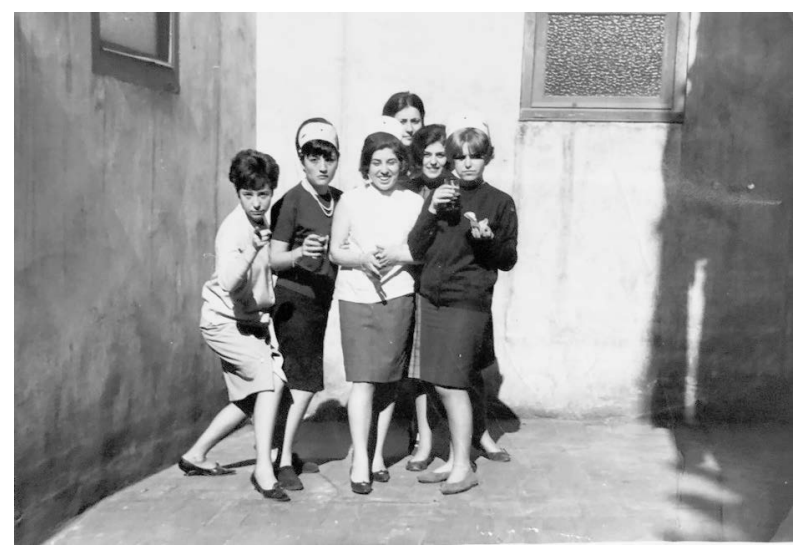

My father...when I had any suitors...there was this woman, a neighbor in our village...and when a young man...a suitor was waiting for me to go out...we would say a sort of "And now, I need to know why so much of a monstrous history." Zambrano, La tumba de Antígona, loc. 748 of 1423, Kindle [my translation].

$9 \quad$ Fragment from Analicia Sotelo, “Do You Speak Virgin?” in Virgin: Poems (Minneapolis: Milkweed Editions, 2018), loc 70,76,85 of 786, Kindle. 
boyfriend...that neighbor sneaked up on us and would tell my parents...and then my father and mother would order me to take off my dress. I would cry and complain, "I have done nothing wrong." "TAKE OFF THAT DRESS YOU ARE NOT GOING ANYWHERE." ...Then I finally found out that the neighbor was telling them. You see, having many suitors was not right because then you were considered a whore... I was a very happy, very friendly young girl... ...Well, I didn't know anything about sex [Valentina emphasized]. Nothing at all. When I got my first period, I knew nothing. I found out more about it from a girlfriend who told me. [pause] And I put on some rags that I took away from my mother. I used to wrap them in newspapers or some sort of papers and hide them under the mattress. Can you imagine? Of course, my mother didn't know that I had gotten my first period and that I was now a woman. At thirteen, I got it...just in July, I got it...I waited for her to leave the house for me to wash my rags. I hid them...because I was embarrassed and because I believed...I don't know...that whatever was happening to me was something bad.

Sex? More of the same. Sex, I had never in my life heard talk about sex at all in my house. I just remember how I heard my mother moan many nights. Two and three times. My father must have been rather potent or... a brute or whatever. And then I saw them...because there were no doors separating the rooms, only curtains. But after two or three times she would get into bed with me. She would whisper, "make some room for me." And I used to say, "Mama, did Papa hit you?" Of course, because I could hear her moan. So, I feared that my father might have hit her or something and that is why my mother got into bed with me. My father might have been demanding... and she was running away...because she didn't want any more children. We were already all big kids and enduring so much misery she didn't want any more children. And that's the only thing I knew about sex. [Valentina reflected, looking at me intently] I know now, what all that was...all that.

And like that, over time I found a boyfriend. My boyfriend was, well, as I tell you, a ladies' man. A man who knew women... a man seven years older than me...handsome...with great presence... but he also liked going out, he liked women, he liked a glass of wine. He grew up with his grandmother...well...his parents...he didn't love them...he really didn't love them. He grew up with his grandmother; his grandmother gave him everything...heaven if need be. But still he had to give his parents his wages and they didn't give him any money. Even during his military service, he would work when visiting the family because his father had little handyman jobs.

I remember, I went to Camas in the Sevilla area to the festivities and stayed with relatives fifteen days and so I came back a little chubbier and wearing pretty summer dresses an aunt of mine, who was well-to-do, made for me. I came back that year that I turned fourteen and Antonio noticed and liked me. But he was older...and my father worked with him in construction. Whenever Antonio had a construction job, he would hire my father as his helper. So, what happened with Antonio? Well, he lived in a house on the same street and his balcony overlooked mine. But he just looked at me...observed whenever I went out and when I came in after lunch. He used to read many Wild West novels. He would tell his mom, "I am going upstairs, if I fall asleep, wake me up." But it was a lie. He would start reading on the terrace 
but the terrace was covered like this...walled up...made of perforated bricks like a thick lattice and all he wanted was to look out to see me leave and to see me enter. But he never got to speak to me until I turned eighteen. He liked me in silence all that time and never said a word to me.

Only a week before I was to go to Barcelona, he stopped me. Because, you see, I had at that time three suitors and my parents wanted to kill me...they followed me to death...my mother... whenever there was a dance they forbid me, "don't go to dance." "Mama, I'm not going." ...The minute I arrived at the dance...because, you know, maybe my girlfriends would convince me, "How is your mother possibly going to find out?... How is she going to find out?" I don't know what it was...if she had telepathy or what...but the instant I reached the door of the dance my mother was already there. And she pulled me back home, beating me all the way to our house [Valentina recounted all this while laughing] for having lied to her. Because one could neither lie nor could one blaspheme [continues laughing] nor could anyone do anything fun...you had to be a saint. If I were to say "darn," she would slap me in the mouth. [Laughs] Anyway, I then resigned myself to not going to the dance. On Wednesdays there was something called "femina" which meant that the girls could enter for free if accompanied by a guy. She, my mother, knew it somehow. If we planned a stroll downtown, she was already at the cinema's entrance waiting for me to take me back home. My friends were free, and I had to go home. [Pensive pause] So about sex NOTHING. Sex...I didn't even know how to kiss, or touch...I didn't know where they would touch me. You washed yourself and there were times when I went to where we had the chickens and pigs for privacy. I washed up there...I would put water in a pot on the stove and then and there [referring to the corral] I washed. But you had to go out dressed and you had to get out of it... Many times I had put water on the stove and was not quick enough, so my brothers took it and I had to wash up with cold water. We had to go get the water at the well because we didn't have a water tank. A lot of hardships, Auri [she called me by my childhood nickname, lovingly] ...in every sense of the word. Because then you had no intimacy or trust to confide in your own mother. "Mama, look, this is happening to me...Mama, that other thing happens to me." ...Once, I remember during Holy Week the Via Crucis took place. Well, I already told you I was very pious then...I was with my girlfriends out during the...the Via Crucis and they let out all the young soldiers from Grana(da) [she laughs] and we had two or three soldiers following us. I became so agitated that I got an awful nosebleed. And then I remained in bed for a month, and they gave me some transfusion and all kinds of things to recover. It was as a result of the terror...that it gave me...just to think that I was followed by three soldiers and that my mother and that my father would kill me if they saw me.

Well then, I went to the dances and I don't know what the hell happened to me that one guy really liked dancing with me. By the time I went back home my mother knew who I had been dancing with, whatever I had done, whatever I had not done...even more than what I had really done. DANCE! "Mama, please I have not done anything but dance"..."YOU HAVE BEEN DANCING FLAMENCO?... DID YOU TURN AROUND?"... I would say, "Well, of course in a dance you turn around and around,"... "AND WITH THE CANCAN DRESS 
YOU WORE YOU HAVE SHOWN YOUR LEGS?”... “Mama please, I haven't...been looking down"... to all that yelling I tried to respond very calmly...you know?... I have never in life ever been able to dance with a person who I did not know. He always had to be known by the people in the village and have an upright life. Let's say they would say, "That guy drinks, or he is a womanizer." ...I had to be exclusively like that, otherwise I would have to sit in a chair and not dance at all...all night long. That was my life!!

My parents did not like Antonio as a boyfriend for me. A week before I left for Barcelona, Antonio told me, "Look, I've liked you for so long. I didn't want to say anything because your parents are going to object. Because they know that I love women, like any man, and that if I get drunk...I do drink a glass of wine occasionally. Your father knows me very well and I know he does not want me to pursue you." Because you see...there was a class rank between our families...meaning that, although we did not have a cent, I belonged to a well-to-do family, something important at the time, and Antonio came from a lower-class family.... Well, we started to write letters to each other and one day my father found one of his letters and said, "What is this?" Antonio's family was known by the nickname "Pollero" and he was called Antonio Pollero.... Are you corresponding with the Pollero's son?" ...I said, "Well, yes."...And he said, "Well, look I'm going to tell you something, I do not like it." ... I said, "Well"...by then we were in Barcelona... and I said, "Look, I'm truly sorry, but I like him."... [Valentina paused] He replied, "Well, I'm going to tell you something in one word." ... He did not tell me "Antonio is a womanizer,"...he called him "a whoring man and a drunk" and added, "but you will never lack something to eat in your house nor some money to put away." I mean he said something good and something bad. Then they talked...of course because they [referring to her parents] knew I was seeing him, so, they talked and Antonio proposed.

Well, it turns out that Antonio came at the end of the year. He used to come visit once a year to Barcelona because he migrated to France... when he became my boyfriend...I moved [to Barcelona] in September and he had moved in January to Strasbourg in France and visited us for Christmas. Every Christmas. He stayed fifteen days in my house... Where would he stay otherwise? Not at a pensión because we all had known him from our village, so he stayed at my house. He stayed in the same room with my brother. Well, after two or three days he asked permission from my mother... "Look, I'm leaving soon... since here in Barcelona there are cinemas with matinees showings, Tina could leave work a little earlier... a couple of hours earlier and that way we would come back with her sisters after they finished work all together." SO, we went to the movies! [Tina and Antonio, alone without chaperons] And I kept pulling him to the front rows... and he said, "no, no here in the back," ... and I thought it odd...to go so far back to see the movie, well,...but we did go to the back. And when we sat down I said, "Oh, Antonio there is nothing but couples here [Valentina giggled happily] all kissing, kiss comes and kiss goes. I told myself, "Here I perish." Of course, he gave me a kiss, a small quick one. Well, I liked it so much, to be frank, and after that first one there were seven or eight or I don't know how many more. [We both laughed and relished the moment of happiness she was describing] I became so skilled in such a short time. 
Then the time came for him to depart again and for two years...in those two years [she paused] there was a crisis between the leftists and the rightists...Antonio was always for the workers and immigration found out and made sure that he could not come back, because what he defended was left-wing; then he left and he could not come back for two years. Exiled, because if he came back, they would lock him up...as a political prisoner. In those two years he proposed marriage by proxy and my parents didn't want to... and I...it took me three or four months to write. And in those three or four months, as I had already kissed him, I believed that the kiss brought pregnancy. Well, I sobbed constantly [laughing], "He has impregnated me and now he's gone, and does not write to me... and now what do I do? How do I tell my parents?" ...And although my period came regularly, I was convinced I was pregnant. Until his sister wrote to the consulate asking about him since he didn't write. And then he sent her a letter, writing, "Sister, please leave me alone. I don't write to my girlfriend and you certainly must not write to me. [silence] Tell my girlfriend that I love her and I will love her till death. If she wants to wait for me so be it; if she doesn't, she is free to do as she wants. I can't say any more." I had other suitors, but I...I liked...my husband-to-be, no one else.

Well, that was in [19]64 and he could not come until [19]66, and he asked me to take care of the paperwork as he planned to return in ' 66 for us to get married... when he came back here from France. But I told him that I would not arrange any papers because with the experience I had had not knowing the reason why he did not write, I would not do it.... Then he asked for a month leave to go to Barcelona and on November 15, 1966- a Tuesday it was-we got married. Civil and church ceremonies, because he was not a church supporter, but I was and my family also and because then it was very frowned upon to marry only in court... We got married. I spent a very happy day, very happy [emphasis]. I sincerely tell you from my heart.

That was my first time. He noticed I was so very nervous and took me for a stroll down the Ramblas to a hotel. In that hotel...he saw that I was still very nervous. I did not bring any luggage. I did not want anyone to know that I was just married. Imagine how little experience. [Valentina ran out of words, frustrated by her memories of that moment] My innocence was so great. He was a man with a lot of experience. Well, he called the hotel but they said that there was simply a room with two beds and so we said yes...he said yes...well, a room with two beds. I only carried an overnight bag because we planned to stay in that hotel four days, and I only carried a bag just to change and he had told me to bring a bed sheet...or rather, a bath towel... just that. [She stopped. Silence] "Antonio, what do I want a bath towel for?" And he said, "Bring one with you, I will explain...nothing might happen, but something may happen." Well, I was trembling like...but also full of desire [with emphasis] to be able to hug him...I'm telling you, Auri [Valentina called me by my childhood nickname again].... At the wedding banquet he whispered in my ear all the things in life we were going to do... It was unforgettable, but he kept noticing my anxiety. Anyhow, he asked for the hotel room and we went in. We acted like a normal couple. They asked us at the hotel, "Do you have any more luggage?" And he replied, "No, because I come from France...we come from France," and he said, "We didn't bring anything more than this luggage because 
we are leaving soon." ...So each one of us sat on a bed and started talking normally... "How did you enjoy the day," etc.... to put me at ease...I was very tense and he continued the conversation always very casually to distract me. Until he said, "Do you want to take a shower?" And I quickly said I would really like a shower. Then he said, "All right, go into the bathroom...in the bathroom, take your shower and if you brought a nightgown or you brought something special to wear, put it on if you want or not, if you do not feel like it. Do as you want." Well, I put on my nightgown, my underwear, my bra, my nightgown.... [She enumerated, amused, the multiple garments she wore in the bathroom] I put on ALL those clothes. AND JUST STAYED THERE. And fretted, "Now, how do I go out dressed like this?... [She laughed looking at me] and "Now, how can I possibly come out? My God, how embarrassing to show myself in my nightgown!! Oh no, how distressing!" And then suddenly I hear him on the other side of the door, "Tina, are you all right?" and I replied, "No, no, no." He said, "Don't worry, take all the time you need." Trying to make me feel better...to reassure me because I was so scared and anxious that I had not even eaten all day.... Eventually, I walked out and then he exclaimed, "My God, YOU ARE BEAUTIFUL!" Those were his first words...and he gave me the first kiss and then...then he got in the bathroom and put on his pajamas... and we started talking again. He was sitting on his bed and I sitting on the other. This went on and on until at least five in the morning. At five in the morning, we couldn't take it anymore. We constrained ourselves a lot. At five in the morning he started... and he told me not to worry that... he would behave as the true gentleman that he was. Because he started this and the other...I did not know what that thing was. BUT IT WAS NOT TRAUMATIC AT ALL. FOR ME NONE. [Valentina remarked emphatically] It wasn't traumatic. Just that I was so extremely nervous because we tried intercourse for the first time... and I again went into a panic as I expected that would be worse of an experience and at the same time felt so much desire...so much that it did not happen, anything painful... just... just a small blood stain... a little [soft voice] and that's it. But suddenly I began to cry, and cry, and cry, and cry, and cry. And he soothingly asked me, "Why are you crying?" and I told him I didn't know why. Then he tried to comfort me.... "There must be a reason;... do you regret it?"..."NO, Antonio, I AM NOT SORRY." "Have I hurt you? Do you feel bad?"..."NO, Antonio I do not feel bad." ...And then he started crying too. And it was my turn to comfort him. "Antonio, and now what happened to you? And now what happened to you?" "Well, it moved me to see you cry."

The next day...I told him, "I do not want to exit the hotel at ten or eleven in the morning. Please let's go out early. I don't want people to notice anything; I've been told it shows [she referred to having had sex] when walking...this and that...." So that was what we did. At 8:30 in the morning we left and went to the airport, to see the airport, just to go somewhere.... Well, then came the second night, and we started the...the same talk, and talk and with a lot of patience... much too much patience and again I began to cry because my nerves got in my stomach. I wanted to eat and could not and poor Antonio said that it could not be like that, that it could not be...that I had to eat. [emphasis] And so he started crying again. [Valentina laughed nervously, recounting the moment] Then I told him...I said, "Antonio, what is 
wrong with you?" And he then asked, "No, what is happening to you? Is it hard for you to have lost your virginity and marry me?" And in that instant I reassured him, "NO." [She started crying softly] I told him that the only good thing that had happened to me in my life at my age was to have married him. [I held her hand and we stayed silent for a little while. Tears rolled down her beautiful sad face.] I said it then and I keep saying it; even after I had our children...WELL, THE GREATEST HAPPINESS OF MY LIFE WAS MY HUSBAND ANTONIO [she continued crying. I cried too].

Antonio died of liver cancer in 1985. He was forty-nine years old. He fathered three children: two girls and one boy. Tina was forty-two when he died. And I don't miss going out. I long for solitude. I like being alone. With his memory. With his image here. [she pointed to his picture on the other side of the room] I talk to him. He grants me everything. Maybe it's a coincidence but whatever...he grants it to me up to this day. And with regard to my parents...I was taking care of them until the last moment...they died too. Antonio died in my arms. I helped the nurses get his body prepared to be buried and now I live...with the loving memory of my husband. Now I live the joys my grandchildren grant me, but I miss him dearly.

\section{ACT III: Without Antonio}

Me dejas sola con mi memoria, como la araña. A ella le sirve para hacer su tela. Esta tumba es mi telar. No saldré de ella, no se me abrirá hasta que yo acabe, Hasta que yo haya acabado mi tela. ${ }^{10}$

Figure 35: Construction workers posing on top of a scaffold

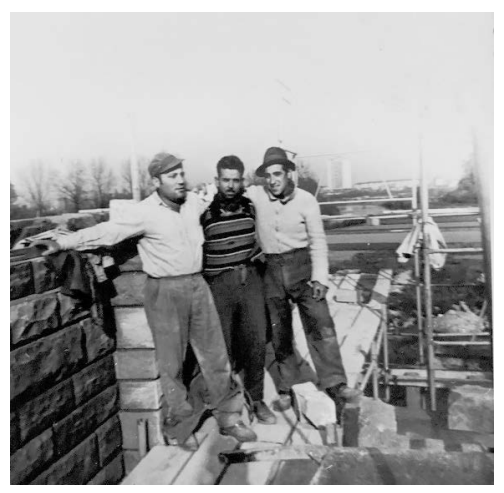


We openly raise the word

from hard ground and roots.

From every dark blow received

we openly give you testimony.

This is our voice and our struggle,

our blood shed, inevitable

like the bitter sweat of the hours

endlessly worked without a beginning.

Our skin stings, this second

skin of night men, which does not arise

from the light, but from death,

in the rain, the sun and from the lash.

There were not just three. We remained

all on the shocked ground,

discovering suddenly, once again,

the hidden meanings of things.

We have not cried, it is true. This pain

it doesn't fit within naked tears.

it only emerges if it is shared

with every man and transformed into acts. ${ }^{11}$

Antonio was seven years older than Tina. He had worked in construction since he was a teenager and had migrated to France around the same time Tina moved to Barcelona with her father and older brother. Through the labor movements in France and Spain he had been involved in leftist politics.

According to an October 1969 study on the evolution of prices and the cost of living carried out by the Vice Secretary of Trade Union Organization in Granada, the wage of a construction worker in Granada was not only insufficient to meet

Luis González Palencia, "Granada, July 1970," in Andalucía: tierra cercada (Bilbao: Zero, 1977): Abiertamente alzamos la palabra desde la tierra dura y las raíces. De cada golpe oscuro recibido os damos testimonio abiertamente. Es esta nuestra voz y nuestra lucha, nuestra sangre vertida, inevitable como el sudor amargo de las horas trabajadas sin fin y sin principio. Nos escuece la piel, esta segunda piel de hombre nocturno, que no surge desde la luz, sino desde la muerte, bajo la lluvia, el sol y el latigazo. No fueron tres tan solo. Nos quedamos todos sobre la tierra sorprendida, descubriendo de pronto, una vez más, las ocultas razones de las cosas. No hemos llorado, es cierto. Este dolor no nos cabe en las lágrimas desnudas. solo tiene lugar si es compartido por cada hombre, y transformado en actos. 
the minimum needs of clothing, furniture, appliances, health, transportation and leisure, but did not even cover basic food costs. At that time $34 \%$ of the population were connected to the building trades. According to the Bank of Bilbao, in 1955, Granada occupied the last place on the national list, with an average income per inhabitant of 5,613 pts (about $\$ 500$ in today's money) compared to 24,777 in Guipuzcoa, which was the first. ${ }^{12}$

During the era of "desarrollismo" (economic development plans), Granada was able to access the aid provided by the International Monetary Fund and the World Bank. Thus, in 1969 these grants arrived in Granada as part of the Second Development Plan of 1968-71. With them, Franco invested in infrastructure such as the construction of the airport. However, job creation expectations were not fulfilled for more than $48 \%$ of the population, which resulted in an increase in emigration from the province. Tina and Antonio represent the changing face of labor in the early 1960s. According to Carme Molinero and Pere Ysàs, 1962 marked the beginning of a stage of mobilizations driven by economic transformation and the new labor activism marked by the birth of the so-called CCOO. CCOO benefited from the regime's attempt to liberalize labor relations. General Secretary José Solís ${ }^{13}$ and the National Delegate of Trade Unions bet on the new formula of collective contracts and elections of union representatives. This is how the Communist Party and other trade union organizations such as HOAC were able to participate in union elections and to negotiate better working conditions.

Established in 1943, HOAC operated with the directives of the Vatican in the spirit of re-Christianizing the labor movement. In the regime's sponsored union elections of 1963, the HOAC and the JOC gained support. The encyclical Pacem in Terris, published that same year by Pope John XXIII, was instrumental in opening the dialogue between Catholics and Marxists in both the workers and student movements. Likewise, the participatory assembly became a new legal venue to claim labor rights within the new opening formula the Labor Ministry articulated. ${ }^{14}$

CCOO was legalized in 1967 and shortly after, Antonio joined and became a union liaison in the organization for the construction guild. Valentina remembered the time when he went to training: "Antonio was in the union, yes. In CCOO. ...They chose him at work.... He was a representative...sure, ...yes! And he had to do a training or something over there at...what is that?... They gave him a framed

12 Enrique Tudela Vazquez, Nuestro Pan: La Huelga del 70 (Granada: Comares, 2010), 42-43.

13 Molinero and Ysàs Solanes, De la hegemonía a la autodestrucción, loc. 742 of 10995, Kindle.

14 Carme Molinero and Pere Ysas, De la hegemonía a la autodestrucción, loc. 650 of 10995, Kindle. See also Espai en Blanc, ed., Luchas autónomas en los años setenta: Del antagonismo obrero al malestar social (Madrid: Traficantes de sueños, 2008). On CCOO see: Alfonso Martínez Foronda, La conquista de la libertad historia de las comisiones obreras de Andalucía (1962-2000) (Sevilla: Fundación de Estudios Sindicales, 2005) Archivo Histórico de CC.OO.-A Segunda Edición. 
diploma that I still have.... It has on it the hammer and the wheat spikes and what else is it? You know, Comisiones? Well, that was there. He had to do a workshop, but I did not know much about it. Whatever they did...there on the avenue, that building where there is now a fancy hotel...what was there? The unions headquarters...the unions...well, there is where he did a workshop and they gave him a certificate, yes. I didn't go, because he didn't tell me," she paused. "Antonio did not tell me...what he was going to...the workshop or anything...I recently threw away all those papers, but I do keep the diploma...."

Figure 36: There were not just three. We remained all shocked on the ground, discovering suddenly, once again, the hidden meanings of things.

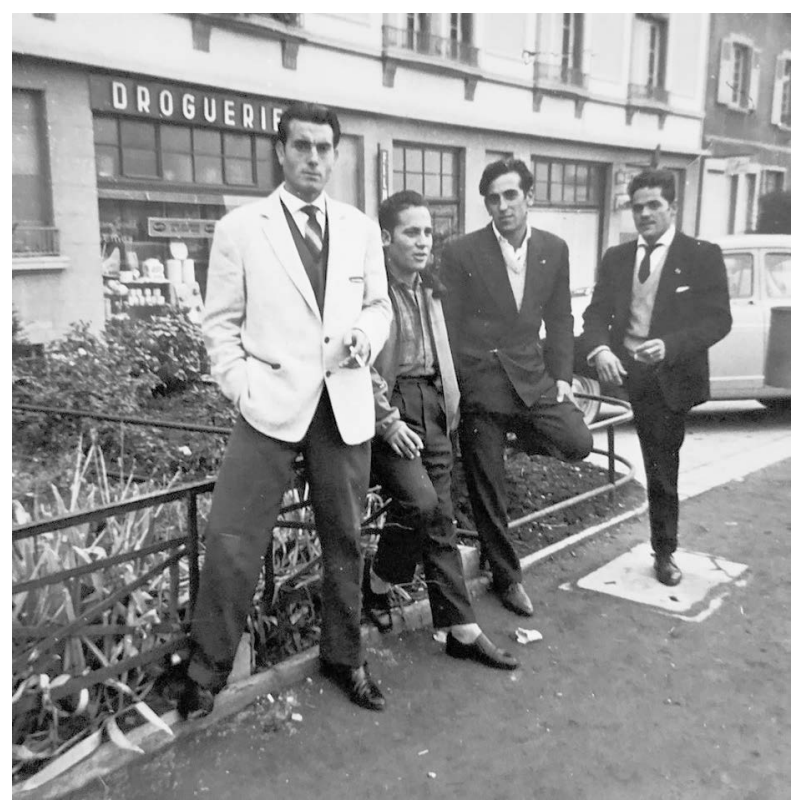


Labor conflict increased significantly in the 1960s. According to the Ministry of Labor's official report for $1970,{ }^{15}$ workers' conflicts in the Basque Country and Asturias played a leading role in the first half of the 1960s, particularly in mining and heavy industry. In Andalusia, the construction workers in Sevilla and Granada were the ones who led the more violent protests, most tragically in Granada during the summer of 1970 with the death of three workers in the confrontation with the regime's armed police. The report responded to the guidelines of the Organizació Internacional del Trabajo (International Labor Organization) and noted 1,595 workers' conflicts for 1970, 317 of those taking place in Granada in July, and 54 in October. ${ }^{16}$ The conflicts increased $30 \%$ in the construction industry as a result of the urbanization and tourism infrastructure boom of the so-called "development years." ${ }^{17}$ Granada benefited, as mentioned above, from government investments in 1969 as part of the second five-year development plan. Nevertheless, Granada's working class endured extreme poverty. Emigration to the more prosperous north or to other European countries was often the best means of survival. Between 1950 and 1970, Granada lost almost 300,000 people, half of its population. Every year about 15,000 people left, bound for Catalonia and other developed regions in Spain, and to the richest European countries. ${ }^{18}$ There were also many people, like Antonio and Valentina, who, after they married, moved to Granada from villages such as Aterfe and Maracena.

Remigio Mesa Encinas describes the terrible working conditions of the construction workers. Apprentices received the lowest wages, about 1,200 pesetas per week, including payments, permits, and family bonuses. They worked ten hours per day, six days a week. The practice of piecework and unreported overtime was widespread, causing a high level of unemployment and underemployment. Contracts were generally four to six months. It was common for workers to go from one company to another on a recurring basis, in addition to having frequent periods of inactivity. Often, workers were fired or had to move from job to job, making it nearly impossible to gain any seniority. Most of the workers' wives worked as domestic servants. The tragic floods of 1963 precipitated the mass relocation of workers' families to the newly established district of La Virgencica where the HOAC and CCOO found their base. Young college students like Socorro [see chap. 2] visited the temporary government housing to help alleviate the suffering and encourage

Ministerio del Trabajo, Informe sobre conflictos colectivos de trabajo 1970 (Madrid: Colección Testimonio, Serie: Informes, Ministerio del Trabajo, 1971), Publications Collection, International Institute of Social History, Amsterdam.

16 Ministerio del Trabajo, Informe sobre conflictos colectivos, 19.

17 "In this period 1961-1973, there will be a 7\% cumulative annual average growth, multiplication by three of industrial production, 5 and finally, the great boom of the 'Spanish miracle.'" Blanc, Luchas autónomas en los años setenta, 35.

18 Remigio Mesa Encinas, "La huelga de 1970 en Cranada” in Luchas autónomas en los años setenta. 
women to support their husbands' political and trade union activism. In La Virgencica the parish priest Antonio Quitián, a construction worker himself, lived among the poorest of the poor, and organized the first neighborhood association to demand from the town hall basic services like garbage collection, paved streets and electricity. ${ }^{19}$ Quitián was instrumental in facilitating the collaboration between the workers and college students. The repression against the construction workers of Granada in the summer of 1970 spurred the students' protests at the beginning of the academic year that ended with the regime's proclamation of the State of Emergency in December and the persecution and incarceration of students.

The summer of 1970 was a bloody one in the history of Granada's labor movement. Since the civil war, there has not been a workers' mobilization of such caliber and violence. Three workers were killed by the police, ${ }^{20}$ and army forces were deployed in the city streets by order of the civil governor of Granada. The conflict raged until, after a long and difficult negotiation between the workers' representatives and the employers to settle the demands for a fair contract, a "convenio colectivo" was agreed upon. The negotiations had started in June and after four unsuccessful meetings, living wages remained the point of heated disagreement. The workers had lowered their initial request of 300 pesetas a day to 240 for beginning mason laborers. Employers were offering 170 pesetas. On July 21, around 6,000 workers descended into the city and stood around the Official Union Headquarters on Calvo Sotelo Avenue (now called Constitution Avenue). An anonymous testimony reports: "From the different distant points of Granada, groups of bricklayers arrived at eight o'clock in the morning, picking up on the way their fellow workers who went to work in the different sites, because they had not heard about the strike, not having attended the gathering the day before." An estimated 12,000 workers participated in the strike. ${ }^{21}$

19 The neighborhood was demolished in 1984. See the chapter on Socorro and Jesus story in this book. On La Virgencica see: Andreo Sánchez, "La Virgencica"; Tudela Vázquez, Nuestro Pan; Quitián González et al., Curas obreros en Granada. Ibáñez Encinas, 43 years old from Granada; and Manuel Sánchez Mesa, 24 years old from Armilla. 
Figure 37: Aerial view of La Virgencica bee-hive shape design housing for the poor, 1969

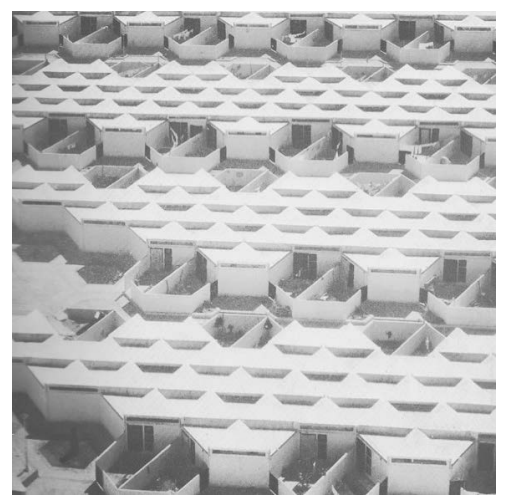

Valentina was still afraid to talk about the strike and the tragic episodes that unfolded on July 21, 1970. To this day, she is convinced Antonio prematurely died as a result of the beating he received in prison that summer. I asked her where she was when the conflict between the construction workers and the police started on that day. It is then that she opened up to me, on the other side of the phone line across the ocean. Me in Miami, pacing around my house while she speaks into my ear from a seaside town by the Mediterranean. She is spending the summer with her youngest daughter and grandchildren. Her voice remains as strong now in 2019 as it did seventeen years after our first recording.

He was working as foreman for Juan ${ }^{22}$...that day at the Sacromonte hotel.... That day a workers' protest took place, and everything fell apart. As he had to pass by the very site of the protest on his way home...he saw some young men from our village and decided to stop and greet them. And that's when everything exploded. The troops from Sevilla and Málaga had already come and I don't know from where else... the police. And that's when everything went crazy. They [referring to the police] started...shooting and they caught him because they arrested many.

He was hit. He had marks all over...from the beatings, bruises on his legs... and I don't know any details as Antonio spoke so little about it. But I did see clearly that he had been badly beaten...I saw those bruises...it all started on July 18 and lasted until July 25 or more.... It lasted at least ten or twelve days...locked up,...yes. They kept them more days at the police

22 This is not his boss' real name. I have changed all names and places to respect Tina's wish for their privacy. 
station than was legally permitted. And then they took him to jail. I did not go to visit him in jail, because my father-in-law didn't want me to. And Miguel [referring to a neighbor in their building who was very religious and sympathetic to the regime] was the one who pleaded for help... I told him, "Miguel," I said, "Miguel, can you see about Antonio?" And he said, "I was going to ask you, but those things are very delicate... and I didn't know if you wanted my help or not." And then he added, "But do not worry, this afternoon I'll bring you an answer about when they might let him go." He assured me, "Do not worry, he [Antonio] will come back to you very soon." And sure enough, the next day they let him out.

She paused for a second and retraced the events to make sense in her mind of the circumstances leading to the debacle.

I found out...because, you know... I went down to the drugstore to buy a can of paint, and the shop attendant told me, "Do you have a construction worker in your family? Do you know what is going on?" And I had left my baby boy in the cradle and my little girl in the carriage. And then she, the store clerk, told me, and I replied, "Yes, my husband," and she said, "and do you know where he is?" and I said, "the Sacromonte Hotel," and she goes, "Let's phone right now to see where he might be." The owner answered and told me that a workers' patrol had stopped by the work site where there were other construction workers like Antonio. The masonry workers patrol threatened them if they did not stop working; they stoned them....So then Antonio and the rest of his crew stopped working...they got off and my Antonio called the owner, Juan, to let him know, and Juan said they could all go home. Then Antonio took his motorcycle to come back home, but as he passed by the Union Headquarters on his way, he stopped, took a look around and stopped. And then, it was then the police arrived from Málaga and Sevilla. At that moment a truck loaded with bricks drove by. Some say that they were called [truck drivers]. Of course, since they [the police] started with gun shots, they ran to the truck and began to throw bricks at the police. And then they took him. [pause] And they hit him? Of course, they hit him. And now three [referring to the three killed workers]... and some others...they died later after the confrontations from the beatings they endured. I don't know if Antonio...because nobody told me anything, Antonio never said a single thing to me... and whenever I mentioned it, he would reply, "Don't ask me, don't ask me, Tina; I have lost sleep over this...don't ask me, please." And I, so he would not suffer...would resign myself, "Let's shut up..." and that's it. He got sick as a consequence, of course. He was already sick with liver problems. But then, they tortured him and all that... and he suffered so much too. Because there were young people who were also Communists who had been caught, and he used to tell me they were beaten to death. [pause] That's all I know. Nothing more.

My darling... I loved him so much that I slept all those days...wearing the same dress I was wearing the day they arrested him...day and night. AND I COULD DO NOTHING MORE THAN SEEING HIM AT ALL HOURS...AND SEEING AND SEEING HIM...and there staying with me were my in-laws and my parents. My father-in-law kept telling me, "Don't talk, don't talk...say nothing," [urgency in the voice] just in case something happened to 
my Antonio... and I Shut Up, Shut Up, did not go out...to the street. Buried alive so I would not risk talking. Because you couldn't speak up in those times. So... I remained in my house with my children and with them [referring to her in-laws and her parents] there. My father-in-law brought something to eat to Antonio while he was in jail. I prepared the food for him...but he would not give me his consent to accompany him to the jail.

He was in jail at least ten or twelve days... I think I even...started to stink because I slept in my dress; I would not take it off. In case they came looking for me...in case I had to run.... [urgency in her voice] And I lay awake in that light blue dress I had. [pause] That happened...that way. And then when he came out...for not making him suffer...well, I asked him but as he did not answer, and his tears flooded his eyes...for all the young people from our village who were beaten just because they were Communists. These were young men from the village... They had been throwing leaflets... and he knew them, of course...they were from the village and he knew them. Yes. [pause] So that happened. I don't know if the disease got worse because of all this or he would have had it anyway. He had had...hepatitis, then cirrhosis, but of course as they hit him so bad and that...well...because on his leg, as I told you, he had a black bruise from his groin to the knee...black like a demon...and everywhere else as well. ...You would think he would be compliant, right? No, he was stubborn like a mule!! Like me... a mule. Maybe a while...but eventually the one who looked for him, because he found out... it was his own boss... who found out... because I had called the Sacromonte Hotel. I spoke with Juan...he looked for Antonio in the hospital, not knowing where he would be. ...Looking for him, he went everywhere looking for him... and the motorcycle, Antonio had left it parked in the gardens [near the Unions Headquarters building], and we had to go...Juan and I went to fetch the motorcycle and he kept it in his garage. His own boss was the one who warned me about what was going on. He came to my house and left me 20,000 pesetas ${ }^{23}$ on top of the fridge. He said, "Take it! You might need it." Yes, it was his own boss who went to the hospital... "Don't worry...we won't give up on him...we do not know where he is, though," Juan would tell me. Because you went to the police station and they would tell you that he wasn't there. But there they were indeed, because they were only supposed to be held for fortyeight hours, right? And I think they kept them for at least four or five days. In the Plaza de los Lobos precinct. Yes. They made them stand all the time, all in the same cell. And they slept standing up! leaning on each other's shoulders...Yes. So, don't write our names...don't write our names. Let's NOT tempt luck and after all those years, now they put me in jail. 
Valentina's fear still lives with her. Now seventy-six years old, she pauses and worries about being punished for remembering and telling about what she was told to bury and relegate to oblivion. But time has given her the ability to inhabit her solitude and dwell in her Antigone lineage. Valentina is in a tomb of her own making like Antigone, where she deploys her self-effacing modus operandi for the sake of love and self-respect. In Zambrano's words:

Concealment occurs in this class of beings--(characters and exceptionally human creatures) in a different fashion: when given a grave, and a time of forgetting, of absence as if in a dreamlike state. With this obliviousness they are given time. The time they are owed, which coincides with the time humans require to attain some revelation arising from within themselves. Those are clearings emerging in the forest of History. ${ }^{24}$

I am humbled in her presence, full of might.

24 "La ocultación se produce de otra manera en esta clase de seres-personajes y excepcionalmente humanas criaturas - : una tumba cuando se les da, y un tiempo de olvido, de ausencia como en el sueño. Con este olvido se les da tiempo. El tiempo que se les debe, que coincide con el tiempo que los humanos necesitan para recibir la revelación, que de ellos surge. Claros que se abren en el bosque de la historia." Zambrano, La tumba de Antígona, loc. 369 of 1423 , Kindle. 
